\title{
Absorption and Enrichment Characteristics of Aquatic Plants under Cd Stress
}

\author{
Zhiguo Zhang', Chengnan Ma ${ }^{1}$, Youbiao Hu', Yonghong Zheng ${ }^{1,2,3 *}$, Fangling Chen ${ }^{1}$, \\ Weiqing Cai ${ }^{1}$, Yongqiang Deng ${ }^{1}$, Chao Fang ${ }^{1}$, Zhilin Zhang ${ }^{1}$
}

\author{
${ }^{1}$ School of Earth and Environment, Anhui University of Science and Technology, Huainan, 232001, China \\ ${ }^{2}$ Huainan Mining (Group) Co. LTD, Huainan, 232001, China \\ ${ }^{3}$ National Engineering Laboratory for Protection of Colliery Eco-Environment, Huainan 232001, China
}

Received: 24 April 2021

Accepted: 23 August 2021

\begin{abstract}
In this study, six hydrophyte species (Ceratophyllum demersum, Canna indica, Iris pseudacorus, Pistia stratiotes, Myriophyllum spicatum, and Eichhornia crassipes) were selected to investigate the effects of different $\mathrm{Cd}$ concentrations on the growth and water purification rates in order to identify species with the best $\mathrm{Cd}$ remediation effects. Additionally, a kinetic model of $\mathrm{Cd}$ adsorption by aquatic plants was determined using a regression method. The survival rate of the six species of aquatic plants under Cd stress was $100 \%$. However, Cd stress inhibited the accumulation of biomass and nutrient elements in aquatic plants. Cd was mainly concentrated in the roots of aquatic plants. The simulation result of the kinetic model revealed that the exponential function model was most suitable for describing $\mathrm{Cd}$ removal, indicating that this model can be used to predict the degree of $\mathrm{Cd}$ purification by aquatic plants. The species E. crassipes and $P$. stratiotes were highly efficient in Cd removal, with an average removal rate above $88 \%$. Thus, E. crassipes and $P$. stratiotes are species with potential for use in the remediation of Cd-polluted water in constructed wetlands and floating beds.
\end{abstract}

Keywords: heavy metals, purification, absorption kinetic model, enrichment factor, transfer coefficient

\section{Introduction}

Aquatic pollution is a significant factor in water resource availability and ecosystem degradation. With the rapid increase in urbanization and industrialization, progressively more wastewater and solid waste leachate from various industries (e.g., smelting, electroplating, mining) are discharged directly into water bodies. This increases the levels of heavy metals, which, under

e-mail: zyhaust@aust.edu.cn certain conditions, can be converted into more toxic metal organic compounds. Environmental problems caused by toxic heavy metal pollution have gained considerable attention [1-2]. Unlike organic compounds, heavy metals entering the environment cannot be naturally degraded [3]. They are often deposited in the water column or at the bottom of the water body or absorbed by aquatic plants, and they can pose a health risk to animals and humans upon reaching the food chain [4-8]. As a heavy metal, $\mathrm{Cd}$ is a highly toxic compound; its long-term intake can lead to osteoporosis, embrittlement, spinal deformity, and lumbar disease. 
In Japan, $\mathrm{Cd}$ pollution causes Minamata and Itaiitai (Ouch-ouch) disease [9]. In 2012, an accident in Longjiang River, Guangxi, China discharged large amounts of $\mathrm{Cd}$ into the water, posing a serious threat to the drinking water safety downstream and along the coast [10]. Between 2006 and 2010, rice produced in the Taizhou electronic waste recycling area of Zhejiang Province showed an extremely high $\mathrm{Cd}$ concentration [11]. A survey of six major cities along the Yangtze River, including Wuhan and Shanghai, showed that the pollution rate of heavy metals in these cities has reached $65 \%$ [12]. In $18.46 \%$ of the rivers, Cd pollution exceeded Class III criteria [13].

Heavy metal pollution of aquatic environments has become a significant environmental problem and must be addressed both nationally and internationally. The remediation of heavy metal-contaminated water is difficult: previous physical and chemical remediation projects have involved huge investment, albeit with unsatisfactory results. The use of aquatic plants to restore heavy metal-contaminated water requires low investment costs and is highly efficient. Compared with physical and chemical methods, phytoremediation is considered to be a greener remediation method [14]. Several studies have demonstrated that phytoremediation and sewage purification are highly effective treatment measures [15-17]. Aquatic plants can naturally absorb pollutants and heavy metals; however, there are relatively few studies on the remediation of Cd-contaminated water with aquatic plants.

We selected the six aquatic plant species Ceratophyllum demersum, Canna indica, Iris pseudacorus, Pistia stratiotes, Myriophyllum spicatum, and Eichhornia crassipes as study species. The purification efficiency and enrichment and transfer characteristics of $\mathrm{Cd}$ in sewage by aquatic plants were characterized, with the aim of determining the aquatic plants most suitable for the purification of Cd-contaminated water.

\section{Materials and Methods}

\section{Test Materials}

We selected Ceratophyllum demersum, Canna indica, I. pseudacorus, P. stratiotes, M. spicatum, and E. crassipes seedlings with vigorous and uniform growth and similar individual biomass values. The roots were washed repeatedly with tap water and with deionized water, and the seedlings were pre-cultured with test water for 1 week until new roots grew. The test water was composed of potassium dihydrogen phosphate
$(\mathrm{TP}=5 \mathrm{mg} / \mathrm{L})$ and potassium nitrate $(\mathrm{TN}=20 \mathrm{mg} / \mathrm{L})$ added to ultrapure water to obtain the nutrient solution [4, 17]; the Cd standard solution was added to create polluted water with high, medium, and low concentrations. The minimum concentration of $\mathrm{Cd}$ in the culture medium was determined based on the water quality from the environmental quality standard for surface water (GB 3838-2002), the discharge standard of pollutants for urban sewage treatment plants (GB 18918-2002), and the water quality standard for sewage discharged into urban sewers $(\mathrm{GB} / \mathrm{T}$ 31962-2015). For the medium and high concentrations, this figure was increased by 10 and 50 times, respectively. The initial concentrations are shown in Table 1.

\section{Test Design}

A pot experiment was conducted in a PVC bucket with a diameter of $36 \mathrm{~cm}$ at the top and $27 \mathrm{~cm}$ at the bottom and a height of $32 \mathrm{~cm}$. Each bucket contained $15 \mathrm{~L}$ of test water. The placement of plants was as follows: Ceratophyllum demersum (40 g), M. spicatum (19 strains, 36 g), Canna indica (3 strains, $100 \mathrm{~g}$ ), I. pseudacorus (3 strains, $400 \mathrm{~g})$, P. stratiotes (6 strains, $100 \mathrm{~g})$, E. crassipes (6 strains, $100 \mathrm{~g})$. The specific placement is shown in Fig. 1.

The following treatment groups were set up: high concentration $(n=6)$; medium concentration $(n=6)$; low concentration $(n=6)$; blank control without aquatic plants $(n=3)$; blank control without $\mathrm{Cd}(n=1)$. Thus, there were a total of 22 experimental buckets. The aquatic plant culture experiment lasted for 70 days, and the 14-day cycle was monitored, during which the $\mathrm{pH}$, temperature, and $\mathrm{Cd}$ content of the water were analyzed. Deionized water was used to supplement the water expended by evaporation and sampling to maintain the water levels. To reduce the error, sampling was performed at around $9 \mathrm{am}$, with three subsampling points per barrel; subsamples were mixed to obtain one composite sample.
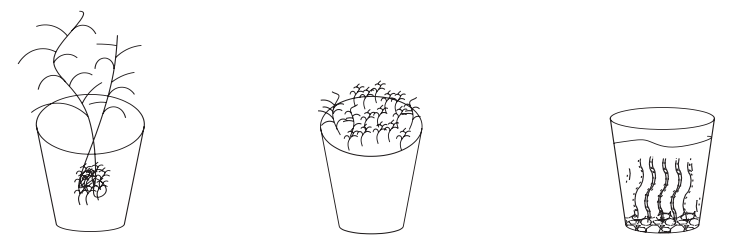

Emersed plant Floating plant Submerged plant

Fig. 1. Placement of the plants in the pot experiment.

Table 1. Initial concentration ratios of the tested water bodies.

\begin{tabular}{|c|c|c|c|}
\hline Water quality index & High concentration $(\mathrm{mg} / \mathrm{L})$ & Medium concentration $(\mathrm{mg} / \mathrm{L})$ & Low concentration $(\mathrm{mg} / \mathrm{L})$ \\
\hline $\mathrm{Cd}$ & 5 & 1 & 0.1 \\
\hline
\end{tabular}




\section{Determination Method and Data Analysis}

\section{Assay Method}

Emergent and floating plants were divided into roots, stems, and leaves, whereas submerged plants were treated as whole plants. Plant height and fresh weight were measured after being washed with tap water and deionized water 2-3 times. To determine the metal contents, samples were dried at $105^{\circ} \mathrm{C}$ for $30 \mathrm{~min}$ and then at $70^{\circ} \mathrm{C}$ to a constant weight and ground to pass through a 60-mesh nylon sieve [18-19]. For each sample, a 0.5 -g aliquot was digested in $\mathrm{HNO}_{3}-\mathrm{HClO}_{4}-$ $\mathrm{H}_{2} \mathrm{O}_{2}$ overnight, followed by analysis using an atomic absorption spectrophotometer (PE AA800).

To determine the $\mathrm{Cd}$ contents in the test water, each sample $(20 \mathrm{~mL})$ was subjected to $\mathrm{HNO}_{3}-\mathrm{H}_{2} \mathrm{SO}_{4}$ digestion, followed by execution of a water and exhausted water monitoring analysis method [20].

The phosphorus and potassium contents were determined via digestion with concentrated $\mathrm{H}_{2} \mathrm{SO}_{4}-\mathrm{H}_{2} \mathrm{O}_{2}$. The total phosphorus content in plants was determined by the ammonium molybdate spectrophotometric method (HJ 671-2013) [21]; $\mathrm{K}$ in water and plants was determined using an atomic absorption spectrophotometer (PE AA800).

For data analysis, the software package SPSS 22.0 (IBM Corp., Armonk, NY, USA) was used. The graphics were drawn using Origin 8.0 (OriginLab, Northampton, MA, USA).

\section{Data Processing}

To determine the transfer coefficient and the enrichment coefficient, the following equations were used:

$$
\begin{gathered}
\text { Transfer coefficient: } \mathrm{TF}_{\text {Floating, Emerged }}=\frac{\mathrm{C}_{\text {aboveground }}}{\mathrm{C}_{\text {belowground }}} \\
\text { Enrichment coefficient: } \mathrm{BCF}=\frac{\mathrm{C}_{\text {plant }}}{\mathrm{C}_{\mathrm{water}}}
\end{gathered}
$$

Comprehensive enrichment factor: $\mathrm{BCF}^{*}=\frac{\mathrm{BCF}_{\text {root }}+\mathrm{BCF}_{\text {stems }}+\mathrm{BCF}_{\text {leaf }}}{3}$ Heavy metal pollution index: MPI $=\sqrt[n]{\mathrm{Cf}_{1} \times \mathrm{Cf}_{2} \times \cdots \times \mathrm{Cf}_{n}}$,

Here, $\mathrm{C}_{\text {aboveground, }}, \mathrm{C}_{\text {belowground, }}, \mathrm{C}_{\text {plant }}$, and $\mathrm{C}_{\text {water }}$ are the $\mathrm{Cd}$ contents $\left(\mathrm{mg} \cdot \mathrm{kg}^{-1}\right)$ in the above- and below-ground plant parts, the total plant, and the water, respectively, $\mathrm{BCF}_{\text {roots }}, \mathrm{BCF}_{\text {stems }}$, and $\mathrm{BCF}_{\text {leaves }}$ are the enrichment coefficients of plant roots, stems, and leaves, respectively, and $\mathrm{Cf}_{\mathrm{n}}$ is the mass fraction of $\mathrm{Cd}$ in the sample $\left(\mathrm{mg} \cdot \mathrm{kg}^{-1}\right)$.

\section{Quality Control}

We used purity-grade reagents and acids. In the determination process, a mixed standard solution of metal elements (GSB04-1766-2004) was used to establish the standard curve, and a plant reference material (GBW10011[GSB-2]) was used for quality control. The determination results of standard samples were within the allowable error range.

\section{Results}

\section{Biomass Variation of Aquatic Plants under Cd Stress}

The biomass changes of aquatic plants after 70 days of growth are shown in Figs 2 and 3. As seen in Fig. 2, compared with the control group $(0 \mathrm{mg} / \mathrm{L})$, plants growing in $\mathrm{Cd}$ solution showed significant inhibition, with greater biomass changes at low concentrations. The biomass changes of I. pseudacorus, $P$. stratiotes, and E. crassipes were higher than those of the other species, indicating a higher pollution tolerance. The descending order of the different concentration groups according to average biomass

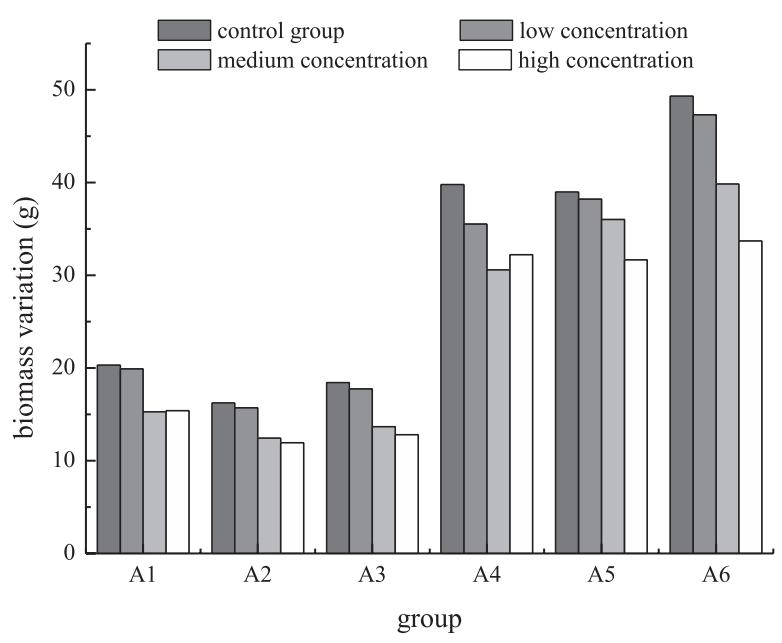

Fig. 2. Biomass variations of the aquatic plant species at different Cd concentrations (0-70d).

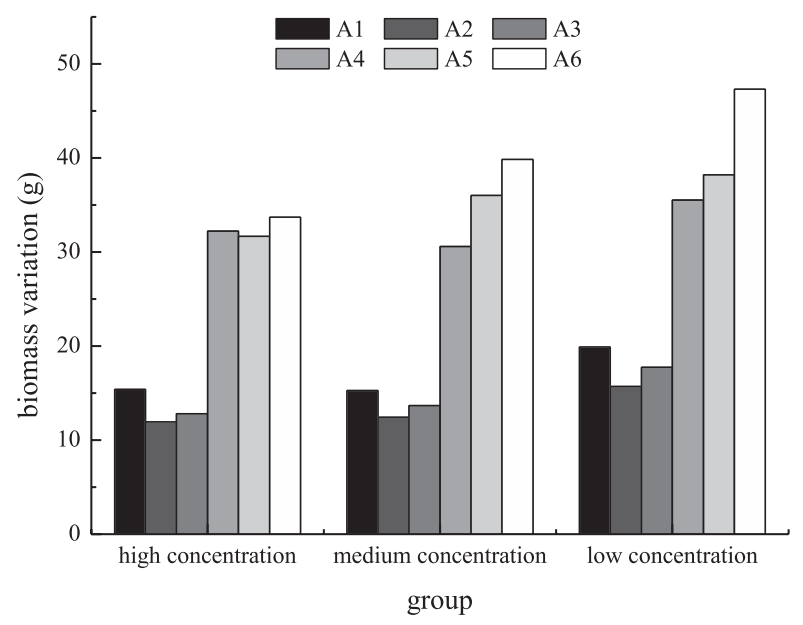

Fig. 3. Changes in the biomass of aquatic plants (0-70d). 
growth rates was as follows: low concentration (24\%), medium concentration (19\%), and high concentration $(18 \%)$. This indicated that the biomass variation in low concentration groups was higher than that in the other treatment groups (Fig. 3). Overall, changes in biomass decreased as $\mathrm{Cd}$ concentration increased. Biomass variation is an important index of the growth status and suitability of plants for remediation. Thus, the tested aquatic plants were able to physiologically adapt to $\mathrm{Cd}$ pollution.

\section{Effects of Cd Stress on Nutrients in Aquatic Plants}

\section{$C d, P$, and $K$ Content Correlation Analysis}

The Pearson correlation coefficients between $\mathrm{Cd}$, $\mathrm{P}$, and $\mathrm{K}$ in aquatic plants are shown in Table 3. The content of $\mathrm{Cd}$ was negatively correlated with nutrient elements and significantly negatively correlated with $\mathrm{P}$ and $\mathrm{K}(P<0.01, n=224)$, indicating that $\mathrm{Cd}$ has a stressor effect on nutrient elements.

\section{Effect of Nutrients on Cd Purification}

The Cd contents of the different organs were determined, and correlation analysis was conducted with the nutrient concentrations (Table 4). The $\mathrm{Cd}$ concentrations in the rhizomes and leaves of aquatic plants were negatively correlated with the contents of $\mathrm{P}$ and $\mathrm{K}$, demonstrating that high concentrations of $\mathrm{Cd}$ result in plant stress. In addition, the concentration of $\mathrm{Cd}$ in leaves of aquatic plants was significantly negatively correlated with $\mathrm{K}$ content $(P<0.01, n=64)$, and the concentration of $\mathrm{Cd}$ in the

Table 2. Experimental design of aquatic plants.

\begin{tabular}{|c|c|}
\hline Category & Test design \\
\hline Blank control group & $\mathrm{K}_{1} ; \mathrm{K}_{2} ; \mathrm{K}_{3}$ \\
\hline \multirow{5}{*}{ Aquatic plant group } & $\mathrm{A}_{1}:$ Ceratophyllum demersum \\
& $\mathrm{A}_{2}:$ Myriophyllum spicatum \\
& $\mathrm{A}_{3}:$ Canna indica \\
& $\mathrm{A}_{4}:$ I. pseudacorus \\
& $\mathrm{A}_{5}:$ Pistia stratiotes \\
& $\mathrm{A}_{6}:$ Eichhornia crassipes \\
\hline
\end{tabular}

Table 3. Correlation coefficients between Cd, P, and K.

\begin{tabular}{|c|c|c|c|}
\hline \multirow{2}{*}{ Element } & \multicolumn{3}{|c|}{ Correlation coefficient } \\
\cline { 2 - 4 } & $\mathrm{Cd}$ & $\mathrm{P}$ & $\mathrm{K}$ \\
\hline $\mathrm{Cd}$ & 1 & & \\
\hline $\mathrm{P}$ & $-0.293^{* *}$ & 1 & \\
\hline $\mathrm{K}$ & $-0.217^{* *}$ & 0.007 & 1 \\
\hline
\end{tabular}

Annotation: $* * \mathrm{P}<0.01$ roots was negatively correlated with $\mathrm{P}$ content $(P<0.05$, $n=64)$.

\section{Purification Effect of Aquatic Plants on $\mathrm{Cd}$}

The purification rate of $\mathrm{Cd}$ in the water was determined by sampling at five time points. During the experimental period, the purification rate of $\mathrm{Cd}$ in water with the aquatic plants was higher than that in the blank control group (anhydrous plants). Based on our results, the six aquatic plants selected in this experiment had varying purification effects. The Cd purification efficiency in the high concentration group continued to increase throughout the experimental period (Table 5). At $70 \mathrm{~d}$, the descending order of aquatic plants based on $\mathrm{Cd}$ purification rate was as follows: E. crassipes (93.41\%), Canna indica (89.20\%), P. stratiotes (89.10\%), M. spicatum (86.69\%), Ceratophyllum demersum (85.97\%), and I. pseudacorus (83.49\%) (Table 5).

The purification efficiency in the medium concentration group continued to increase throughout the experimental period (Table 6). At $70 \mathrm{~d}$, the descending order of the species based on $\mathrm{Cd}$ removal was as follows: Canna indica (95.15\%), E. crassipes (94.07\%), P. stratiotes $(92.65 \%), \quad$ I. pseudacorus (92.65\%), M. spicatum (89.9\%), and Ceratophyllum demersum (85.12\%) (Table 6).

At low concentration, $\mathrm{Cd}$ removal continued to increase throughout the experiment (Table 7). At $70 \mathrm{~d}$, the descending order of the species based on their removal rates was as follows: E. crassipes $(85.60 \%)$, P. stratiotes $(82.70 \%)$, Canna indica $(78.80 \%)$, I. pseudacorus (75.40\%), M. spicatum (67.10\%), Ceratophyllum demersum (39.20\%) (Table 7).

\section{Kinetic Model of Cd Absorption}

\section{Establishment and Prediction of a Cd Absorption Model for Aquatic Plants}

The purification and absorption effects of aquatic plants were analyzed, demonstrating that the species E. crassipes had the greatest $\mathrm{Cd}$ absorption potential. Therefore, using E. crassipes, a linear equation, polynomial function, exponential equation, and compound equation were each simulated in SPSS 22.0

Table 4. Correlation analysis of metal contents in aquatic plants with $\mathrm{P}$ and $\mathrm{K}$.

\begin{tabular}{|c|c|c|}
\hline \multirow{2}{*}{ Cd in different parts } & \multicolumn{2}{|c|}{ Correlation coefficient } \\
\cline { 2 - 3 } & $\mathrm{K}$ & $\mathrm{P}$ \\
\hline Cd root & -0.12 & $-0.29^{*}$ \\
\hline Cd stem & -0.028 & -0.257 \\
\hline Cd leaf & $-0.391^{* *}$ & -0.129 \\
\hline
\end{tabular}

Annotation: $* \mathrm{P}<0.05, * * \mathrm{P}<0.01$ 
Table 5. Cd removal efficiency at high concentrations.

\begin{tabular}{|c|c|c|c|c|c|}
\hline \multirow{2}{*}{ Experimental group } & \multicolumn{5}{|c|}{ Removal efficiency (\%) } \\
\cline { 2 - 6 } & 14 days & 28 days & 42 days & 56 days & 70 days \\
\hline Blank & 5.47 & 9.43 & 15.63 & 16.27 & 16.69 \\
\hline $\mathrm{A}_{1-1}$ & 33.89 & 64.46 & 80.51 & 83.36 & 85.97 \\
\hline $\mathrm{A}_{2-1}$ & 23.03 & 32.74 & 74.59 & 81.41 & 86.69 \\
\hline $\mathrm{A}_{3-1}$ & 29.70 & 40.06 & 84.5 & 85.69 & 89.2 \\
\hline $\mathrm{A}_{4-1}$ & 22.19 & 58.54 & 80.22 & 81.23 & 83.49 \\
\hline $\mathrm{A}_{5-1}$ & 36.19 & 69.75 & 81.9 & 84.69 & 89.1 \\
\hline $\mathrm{A}_{6-1}$ & 48.57 & 75.2 & 85.32 & 90.97 & 93.41 \\
\hline
\end{tabular}

Table 6. Cd removal efficiency at medium concentrations.

\begin{tabular}{|c|c|c|c|c|c|}
\hline \multirow{2}{*}{ Experimental group } & \multicolumn{5}{|c|}{ Removal efficiency (\%) } \\
\cline { 2 - 6 } & 14 days & 28 days & 42 days & 56 days & 70 days \\
\hline Blank & 0.18 & 2.57 & 3.75 & 5.09 & 5.79 \\
\hline $\mathrm{A}_{1-2}$ & 18.89 & 33.96 & 70.13 & 74.14 & 85.12 \\
\hline $\mathrm{A}_{2-2}$ & 15.19 & 50.79 & 80.46 & 81.44 & 89.97 \\
\hline $\mathrm{A}_{3-2}$ & 9.16 & 15.21 & 73.99 & 79.26 & 95.15 \\
\hline $\mathrm{A}_{4-2}$ & 35.29 & 48.22 & 78.26 & 86.60 & 92.65 \\
\hline $\mathrm{A}_{5-2}$ & 40.64 & 56.41 & 81.96 & 90.02 & 92.65 \\
\hline $\mathrm{A}_{6-2}$ & 41.89 & 60.31 & 80.21 & 90.72 & 94.07 \\
\hline
\end{tabular}

Table 7. Cd removal efficiency at low concentrations.

\begin{tabular}{|c|c|c|c|c|c|}
\hline \multirow{2}{*}{ Experimental group } & \multicolumn{5}{|c|}{ Removal efficiency (\%) } \\
\cline { 2 - 6 } & 14 days & 28 days & 42 days & 56 days & 70 days \\
\hline Blank & 0.20 & 0.60 & 0.90 & 1.20 & 3.20 \\
\hline $\mathrm{A}_{1-2}$ & 15.50 & 18.70 & 26.50 & 31.80 & 39.20 \\
\hline $\mathrm{A}_{2-2}$ & 11.60 & 36.30 & 43.00 & 63.70 & 67.10 \\
\hline $\mathrm{A}_{3-2}$ & 13.70 & 28.50 & 40.30 & 64.20 & 78.80 \\
\hline $\mathrm{A}_{4-2}$ & 22.10 & 36.60 & 52.20 & 73.80 & 75.40 \\
\hline $\mathrm{A}_{5-2}$ & 22.00 & 38.10 & 57.70 & 75.30 & 82.70 \\
\hline $\mathrm{A}_{6-2}$ & 22.80 & 51.20 & 65.20 & 75.30 & 85.60 \\
\hline
\end{tabular}

to determine the optimal function model [22]. This can be used to predict the degree of Cd removal by aquatic plants and the optimal harvesting time of aquatic plants to avoid secondary pollution.

This regression equation reflects the dynamics of $\mathrm{Cd}$ enrichment in contaminated water by aquatic plants within a certain period. In the simulation results, the closer $R^{2}$ is to 1 , the better the fit of the regression line. The correlation coefficient $R^{2}$ of E. crassipes for $\mathrm{Cd}$ absorption rates at different concentrations was closest to 1 , indicating it was the best fit obtained; therefore, the most suitable kinetic model to describe the $\mathrm{Cd}$ absorption of E. crassipes is the exponential function model.

As shown in Table 8, the correlation coefficients $R^{2}$ for Cd were close to 1 , with an optimum fitting degree of the regression line. Moreover, the $R^{2}$ values were all significant $(P<0.05)$, indicating a significant correlation. 
Table 8 . Absorption model of $\mathrm{Cd}$ by aquatic plants.

\begin{tabular}{|c|c|c|c|c|c|}
\hline Heavy metal & Simulated concentration & Fit model & $\mathrm{R}^{2}$ & $\mathrm{~F}$ & Sig \\
\hline \multirow{3}{*}{$\mathrm{Cd}$} & High concentration & $\mathrm{y}=4.366^{*} \mathrm{e}^{-0.039 \mathrm{x}}$ & 0.983 & 227.794 & 0.000 \\
\cline { 2 - 7 } & Medium concentration & $\mathrm{y}=1.073^{*} \mathrm{e}^{-0.041 \mathrm{x}}$ & 0.991 & 452.125 & 0.000 \\
\cline { 2 - 7 } & Low concentration & $\mathrm{y}=0.107 * \mathrm{e}^{-0.027 \mathrm{x}}$ & 0.992 & 487.277 & 0.000 \\
\hline
\end{tabular}

Table 9. Measured and predicted values of Cd (unit: $\mathrm{mg} / \mathrm{L}$ ).

\begin{tabular}{|c|c|c|c|c|c|c|c|c|c|}
\hline \multirow{2}{*}{ Days } & \multicolumn{3}{|c|}{ High concentration } & \multicolumn{3}{c|}{ Medium concentration } & \multicolumn{3}{c|}{ Low concentration } \\
\cline { 2 - 11 } & $\begin{array}{c}\text { Measured } \\
\text { value }\end{array}$ & $\begin{array}{c}\text { Predicted } \\
\text { value }\end{array}$ & $\begin{array}{c}\text { Error } \\
(\%)\end{array}$ & $\begin{array}{c}\text { Measured } \\
\text { value }\end{array}$ & $\begin{array}{c}\text { Predicted } \\
\text { value }\end{array}$ & $\begin{array}{c}\text { Error } \\
(\%)\end{array}$ & $\begin{array}{c}\text { Measured } \\
\text { value }\end{array}$ & $\begin{array}{c}\text { Predicted } \\
\text { value }\end{array}$ & $\begin{array}{c}\text { Error } \\
(\%)\end{array}$ \\
\hline 14 & 2.5715 & 2.5291 & 1.65 & 0.5811 & 0.6044 & 4.01 & 0.0772 & 0.0733 & 5.03 \\
\hline 28 & 1.2400 & 1.4650 & 18.14 & 0.3969 & 0.3404 & 14.23 & 0.0488 & 0.0502 & 2.95 \\
\hline 42 & 0.7340 & 0.8486 & 15.61 & 0.1979 & 0.1918 & 3.11 & 0.0348 & 0.0344 & 1.07 \\
\hline 56 & 0.4515 & 0.4916 & 8.87 & 0.0928 & 0.1080 & 16.39 & 0.0247 & 0.0236 & 4.49 \\
\hline 70 & 0.3295 & 0.2847 & 13.58 & 0.0593 & 0.0608 & 2.59 & 0.0144 & 0.0162 & 12.25 \\
\hline
\end{tabular}

\section{Model Calibration}

The error comparison between the predicted and the actual value reflects the predictive value of the model [22]. Predicted concentrations of Cd can be obtained by substituting the interval between acquisition time and initial acquisition time into the fit regression equation. The error of the fitted regression equation is shown in Table 9. The error of the established absorption model was within $20 \%$, indicating that the function model could well predict the concentration changes of $\mathrm{Cd}$ in water.

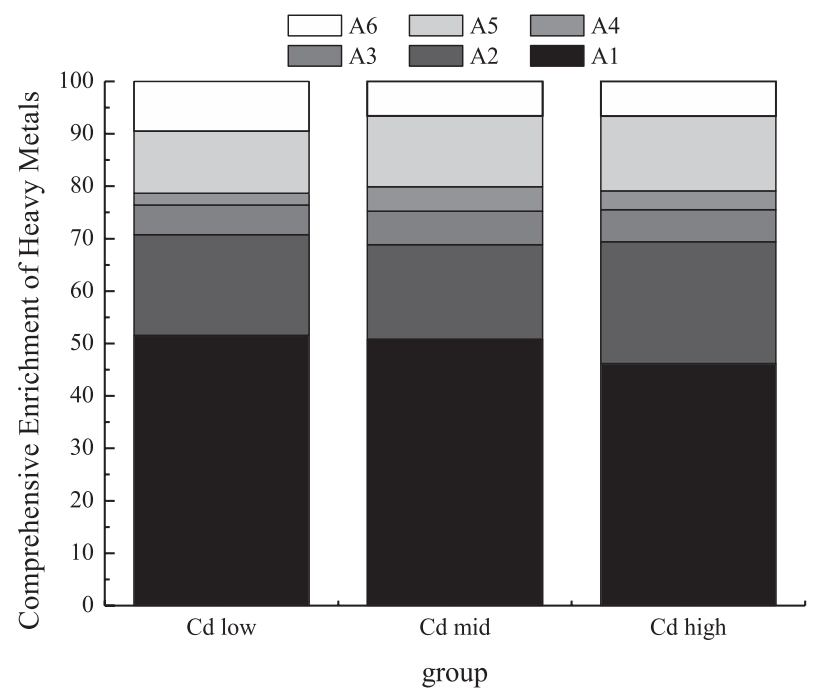

Fig. 4. Enrichment ability of aquatic plants for $\mathrm{Cd}$.

\section{Enrichment and Transfer Characteristics of $\mathrm{Cd}$ in Aquatic Plants}

\section{Cd Enrichment Ability of Aquatic Plants}

The distribution characteristics of $\mathrm{Cd}$ in Ceratophyllum demersum, M. spicatum, Canna indica, I. pseudacorus, $P$. stratiotes, and E. crassipes at different $\mathrm{Cd}$ concentrations are shown in Fig. 4. The enrichment ability of Ceratophyllum demersum and $M$. spicatum was highest. The ability of plants to become enriched for $\mathrm{Cd}$ is higher at low pollution concentrations than at medium and high concentrations. The enrichment of heavy metals by plants is related to the valence of heavy metal elements and the concentration and solubility of coexisting ions of various elements in the environment. Robinson et al. demonstrated that the absorption and enrichment ability of heavy metals is also affected by $\mathrm{pH}$, temperature, nutrition, and other factors [18].

To further analyze and compare the enrichment or accumulation of $\mathrm{Cd}$ in aquatic plants at low

Table 10. Heavy metal enrichment factor (BCF) and heavy metal pollution index (MPI) at low concentrations.

\begin{tabular}{|c|c|c|}
\hline Experimental group & $\mathrm{BCF}$ & MPI \\
\hline $\mathrm{A}_{1-3}$ & $6,254.66$ & 165.82 \\
\hline $\mathrm{A}_{2-3}$ & $2,324.02$ & 60.09 \\
\hline $\mathrm{A}_{3-3}$ & 691.74 & 12.28 \\
\hline $\mathrm{A}_{4-3}$ & 273.18 & 6.51 \\
\hline $\mathrm{A}_{5-3}$ & $1,434.53$ & 25.62 \\
\hline $\mathrm{A}_{6-3}$ & $1,149.42$ & 19.08 \\
\hline
\end{tabular}


Table 11. Cd transfer coefficients of emerging and floating plants.

\begin{tabular}{|c|c|c|c|c|c|c|c|}
\hline $\begin{array}{c}\text { Experimental } \\
\text { group }\end{array}$ & Transfer ratio & $\begin{array}{c}\text { Experimental } \\
\text { group }\end{array}$ & Transfer ratio & $\begin{array}{c}\text { Experimental } \\
\text { group }\end{array}$ & Transfer ratio & $\begin{array}{c}\text { Experimental } \\
\text { group }\end{array}$ & Transfer ratio \\
\hline $\mathrm{A}_{3-1}$ & 0.97 & $\mathrm{~A}_{4-1}$ & 1.2 & $\mathrm{~A}_{5-1}$ & 0.85 & $\mathrm{~A}_{6-1}$ & 2.11 \\
\hline $\mathrm{A}_{3-2}$ & 0.52 & $\mathrm{~A}_{4-2}$ & 0.35 & $\mathrm{~A}_{5-2}$ & 1.06 & $\mathrm{~A}_{6-2}$ & 1.18 \\
\hline $\mathrm{A}_{3-3}$ & 0.48 & $\mathrm{~A}_{4-3}$ & $\mathrm{nd}$ & $\mathrm{A}_{5-3}$ & 1.18 & $\mathrm{~A}_{6-3}$ & 1.97 \\
\hline
\end{tabular}

concentrations, the bioconcentration factor (BCF) and the heavy metal pollution index (MPI) were used, respectively. The results are shown in Table 10. The MPI values of the different species varied significantly. In general, the higher the $\mathrm{Cd}$ concentration in plants, the higher the MPI value. For example, the MPI value of Ceratophyllum demersum in the low concentration group was highest with 165.82 , demonstrating that it had the highest degree of $\mathrm{Cd}$ enrichment. The content of $\mathrm{Cd}$ in the same plant varied significantly, indicating that the plants were affected by $\mathrm{Cd}$. However, the effects of different plants on $\mathrm{Cd}$ pollution were inconsistent. The MPI of heavy metals reflects the degree of pollution by various heavy metals in plants.

\section{Cd Transfer Ability of Aquatic Plants}

The transfer coefficient refers to the ratio of the heavy metal content between aboveground and belowground plant parts, which is used to determine the transport capacity of plants to heavy metals [23]. Table 11 shows the transfer ability of emergent and floating plants to $\mathrm{Cd}$. The transfer coefficients of I. pseudacorus and E. crassipes for $\mathrm{Cd}$ at the high concentration were $>1$, those of $P$. stratiotes and $E$. crassipes at medium and low concentrations were $>1$, and those of the other aquatic plants were $<1$. This indicates that the three aquatic plants I. pseudacorus, $P$. stratiotes, and E. crassipes have a strong $\mathrm{Cd}$ transfer ability. Overall, these four aquatic plants (Canna indica, Iris pseudacorus, Pistia stratiotes, and Eichhornia crassipes) have a weak transfer ability for $\mathrm{Cd}$; $\mathrm{Cd}$ was mostly concentrated in the roots.

\section{Discussion}

In this study, the six aquatic plants grew well in water polluted with different concentrations of $\mathrm{Cd}$, demonstrating that the plant species each had a certain resistance to $\mathrm{Cd}$ pollution. However, the biomass changes of all species decreased with increasing $\mathrm{Cd}$ concentration, indicating that plant growth was inhibited. Under $\mathrm{Cd}$ stress, plants respond with changes in growth status and biomass. Lv Jinyin et al. studied the effect of $\mathrm{Cd}$ on five species of leafy vegetables and found that with increasing Cd levels, the biomass decreased significantly. Heavy metal stress causes changes in plant metabolism, resulting in plant dwarfing, leaf wilting, and reduced biomass, which is consistent with the results of this previous study [24].

In our study, the 70-d hydroponic experiment showed that the aquatic plants exhibited different degrees of $\mathrm{Cd}$ remediation: E. crassipes had the highest removal efficiency for $\mathrm{Cd}$. This is probably because E. crassipes has developed roots, and root adsorption plays an important role in Cd removal from water. The species $P$. stratiotes was also able to efficiently remove $\mathrm{Cd}$, which may be owing to its high biomass and developed roots.

The physiological roles and requirements for various elements vary. Some heavy metals are essential for normal physiological processes, including $\mathrm{Cu}$ and Fe [25]. However, Cd, which is not an essential trace element, has a high biological toxicity. Accumulation of toxic elements not only affects the growth and development of plants, but also human and animal health [4-8]. The present study confirms that aquatic plants have a strong ability to absorb and become enriched with Cd [26], and the enrichment abilities of Ceratophyllum demersum and M. spicatum were highest at low concentrations. Under different concentrations of $\mathrm{Cd}$, the transfer coefficients of six aquatic plants were $<1$, indicating that most of the $\mathrm{Cd}$ was enriched in the roots. $\mathrm{Cd}$ is taken up by the roots of plants, and only a small portion is transported to the aboveground part. The root is the main Cd-enrichment organ [27-28]. Plant roots should therefore be collected after the end of the growing period to prevent secondary pollution. The higher the contents of heavy metals in the whole plant, the higher the MPI value, which reflects the degree of heavy metal pollution in the plant habitat.

\section{Conclusions}

1. The six aquatic plant species grew well under different concentrations of $\mathrm{Cd}$, indicating that they had a certain tolerance to Cd-contaminated water. The descending order of the experimental groups was as follows: control group, low concentration group, medium concentration group, and high concentration group. This indicated that $\mathrm{Cd}$ pollution inhibited the growth of the tested plants.

2. Cd concentrations were negatively correlated with plant nutrient elements, and the concentrations of $\mathrm{Cd}$ in roots, stems, and leaves of aquatic plants were negatively correlated with $\mathrm{P}$ and $\mathrm{K}$ contents. 
3. Absorption dynamic models of $\mathrm{Cd}$ in water by aquatic plants were established by regression analysis, which revealed the best absorption model was the exponential function model.

4. Under different $\mathrm{Cd}$ concentrations, the transfer coefficients of the four emerging and floating plants were $<1$, indicating that most $\mathrm{Cd}$ was enriched in the roots. The comprehensive enrichment ability increased in the following order: Ceratophyllum demersum, $M$. spicatum, and $P$. stratiotes.

5. E. crassipes and $P$. stratiotes had high $\mathrm{Cd}$ removal efficiencies. These plants can be used in the remediation of Cd-polluted water, and our study provides a scientific basis for the design of constructed wetlands and floating beds.

\section{Acknowledgments}

This research was supported by the Natural Science Research Project of University in Anhui Province (No. KJ2018A0072), the National Natural Science Foundation of China (No. 51904014), and the Postdoctoral Foundation of Anhui Province (No. 2019B337). The authors appreciate the constructive comments from anonymous reviewer.

\section{Conflict of Interest}

The authors declare no conflict of interest.

\section{References}

1. SONG Y., YANG Y.Y., WANG Y.T., FU Q., SONG J.B. Absorption and accumulation of plumbum by phragmites root system in wetland sediments. Journal of China College of Environmental Management, 29 (1), 462019.

2. ZHOU Q.Q., REN B., LI Y.Z., NIU Y.D., DING X.H., YAO X., BIAN H.L. Trends and sources of dissolved heavy metal pollution in water of rivers and lakes in China, 39 (8), 2044, 2020.

3. CHEN G.L., FENG T., CHEN Z., LI Z.X., CHEN Y.Q., WANG H.H., XIANG Y.C. The influences of $\mathrm{Cd}$, $\mathrm{As}, \mathrm{Pb}$ enrichment by submerged plant on its Ca uptake. Journal of Ecological Environment, 26 (5), 857, 2017.

4. CHEN X., LIU X.L., TANG T. Advances of bryophytes in response to heavy metal stress. Biotechnology Briefing, 36 (10), 191, 2020.

5. HONG Y.J., FENG C.L., XU Z.X., LIAO W., YAN Z.F., LIU D.Q., FU Z.Y. Advances on ecotoxicity effects of heavy metals to aquatic organisms and the mechanisms. Environmental engineering, 37 (11), 1, 2019.

6. DU Y.M., WU Q.H., KONG D.G., SHI Y.F., HUANG X.X., LUO D.G., CHEN Z.X., XIAO T.F., LEUNG J.Y.S. Accumulation and translocation of heavy metals in water hyacinth: Maximising the use of green resources to remediate sites impacted by e-waste recycling activities. Ecological Indicators, 115 (5), 2020.

7. YANG D., ZHANG H., ZOU H.L.,YI X.H., FANG Y.Y., CHEN N., WEI X.D. Accumulation, subcellular distribution and chemical forms of cadmium in aquatic plants. Northwest Botanical Journal, 38 (4), 100, 2018.

8. IMRAN U., MAHAR R.B., ULLAH A., SHAIKH K. Seasonal variability of heavy metals in Manchar Lake of arid southern Pakistan and its consequential human health risk. Polish Journal of Environmental Studies, 30 (1), 163, 2021.

9. PENG H., DENG H.J., XU H.R., CHEN Y.C., CHEN Q.H., XIAO G.Q. Effect of lime on biochar and humic acid controlling cadmium uptake in rice. Environmental Science of China, 40 (1), 329, 2020.

10. WANG Y., TANG Y.K., THONGSALAK S., XU Z.Y., WEI L.Y., ZHEN G.Y., LIANG Y. Effects of decomposition process of aquatic plants on the fate of heavy metals in water:a review. Environmental pollution and prevention, 39 (7), 794, 2017.

11. FU J.J., ZHANG A.Q., WANG T. Influence of e-waste dismantling and its regulations: temporal trend, spatial distribution of heavy metals in rice grains, and its potential health risk. Environmental Science \& Technology, 47, 7437, 2013.

12. ZHANG K., LUO S. Progress in technology study of heavy metal pollution control in water body. Journal of China College of Environmental Management, 20 (3), 6264+81, 2010.

13. ZHAO Y. Pollution status and hazard of heavy metal wastewater. Jiangxi Chemical Industry, 2, 207, 2016.

14. HAUPTVOGL M., KOTRLA M., PRČÍK M., PAUKOVÁ Ž., KOVÁČIK M., LOŠÁK T. Phytoremediation potential of fast-growing energy plants: challenges and perspectives - a review. Polish Journal of Environmental Studies, 29 (1), 505, 2020.

15. SHAFAQAT A., ZOHAIB A., MUHAMMAD R., IHSAN E.Z., İLKAY Y., AYDIN Ü., MOHAMED M.A., MAY B., MIRZA H., DIMITRIS K. Application of Floating Aquatic Plants in Phytoremediation of Heavy Metals Polluted Water: A Review. Sustainability, 12 (5), 2020.

16. HE H.C., LI Q.Q., CUI J.P., YE Z.T., ZHU N.F. Study on the purification effect of aquatic plant by artificial floating island on domestic sewage. Anhui Agricultural Sciences, 45 (3), 68, 2017.

17. CHEN J.P., HU Y.B., ZHANG Z.G. Water purification of Native aquatic plants in Jiaogang Lake. Soil and water conservation notification, 39 (2), 178, 2019.

18. ZHOU X.L., XIONG J.Q., JIAN M. F. The enrichment of heavy metal pollutants by dominant aquatic plants in Le'an River-Poyang Lake wetland. Journal of Jiangxi Normal University (Natural Science Edition), 2, 104, 2013.

19. WANG B., ZHOU Y.P. Biological purification effects of three aquatic plants on $\mathrm{N}$ and $\mathrm{P}$ in simulated wastewater. Hubei Agricultural Science, 53 (20), 4835, 2014.

20. State Environmental Protection Administration of China and Committee on Monitoring and Analysis of Wastewater. Monitoring and Analysis of Water and Wastewater, 4th ed.; China Environmental Science Press: Beijing, China, 243, 2002.

21. BAO S.T. Soil agricultural chemical analysis method, 3rd ed.; China Agricultural Press: Beijing, China, pp. 147-149, 168-169, 2000.

22. LIU J., WANG Q. Prediction model of heavy metal pollution in Hanzhong section of Hanjiang River based on regression analysis. Journal of Shaanxi University of Technology (Natural Science Edition), 33 (3), 89, 2017.

23. LI J.H., DING W., WENG G.Y., DENG H.J., ZHANG X.Y., ZHANG $X$. Heavy metal accumulation by ten aquatic 
plant species in Minghu National Wetland Park. Journal of Hydroecology, 41 (1), 86, 2020.

24. LU J.Y., ZHANG W., LIU L. Effect of cadmium treatment on $\mathrm{Cd}$ absorption and nutrition quality of edible part in different leaf vegetables. Journal of Nuclear Agriculture, 24 (4), 856, 2010.

25. LI J.C., YU H., YANG S.X., FENG X.Z. Research progress of molecular regulation of iron uptake in plants. Plant physiology, 52 (6), 835, 2016.

26. PAN Y.H., WANG H.B., GU Z.P., XIONG G.H., YI F. Accumulation and translocation of heavy metals by macrophytes. Ecology, 30 (23), 6430, 2010.
27. WU D.M., CHEN X.Y., ZENG S.C. Heavy metal tolerance of Miscanthus plants and their phytoremediation potential in abandoned mine land. Journal of Applied Ecology, (4), 1397, 2017.

28. HUO W.M., ZHAO Z.Q., WANG L., ZOU R., FAN H.L. Study of the effects of intercropping different hyperaccumulator and accumulator plants on Cd uptake and transportation by maize. Earth Science Frontiers, 26 (6), 118, 2019. 
